\title{
The Influence of Citizen Competence on District Level Political Accountability in Uganda
}

\author{
John Mary Kanyamurwa (corresponding author) \\ Department of History \& Political Science \\ Kyambogo University \\ P.O. Box 181, Kyambogo, Uganda \\ Joseph Okeyo Obosi \\ Department of Political Science \& Public Administration \\ University of Nairobi \\ P.O. Box 3019700100 GPO
}

Nairobi

Received: Jul. 26, 2020 Accepted: Aug. 14, 2020 Online published: Oct. 13, 2020

doi:10.5296/jpag.v10i3.17428ＵRL: https://doi.org/10.5296/jpag.v10i3.17428

\begin{abstract}
Citizen competence in a democratic society is perceived as an essential mechanism for promoting political accountability in local governance. This paper, thus, qualitatively investigates the relationship between citizen competence and political accountability in Uganda's local governance system across two discrete political regimes, during the post-independence period. Using an in-depth explorative design, it was established that citizens in both regimes were largely inarticulate, disengaged and uninvolved in determining local preferences, suggesting minimal link between citizen competence and the propensity to promote political accountability at district level. The data suggested that citizen competence was less influential in district politics for the greater part of the post-colonial period. Nonetheless, there were also episodes where citizens actively participated in enforcing political accountability at the grassroots under multiparty politics in both the Obote II and NRM regimes, with slight variations in the intensity and pattern between the two periods. Thus, the level of citizen competence and nature of local governance in Uganda mirror the political accountability practices at the local level, mainly shaped by civic challenges and the character of politics in Uganda during the periods studied regardless of differences and
\end{abstract}


longevity. The paper recommended deliberate state intervention for mobilization of citizens and the establishment of state-engineered dynamic social networks to generate capacity for holding local leaders accountable and more empowered civil society to construct robust citizen competence programmes to foster political accountability.

Keywords: citizen competence, district politics, political accountability, local governance

\section{Introduction}

Scholarly efforts to explore citizen competence and its role in promoting political accountability are not new in the discipline of political science. Indeed, political discourse clarifies on the strength of citizen competence in both developed and developing countries, where three major distinctions have been identified. Firstly, this discourse authenticates opinions influenced by politicians' special economic interests at the expense of the public good, with the state actively undermining existing political accountability mechanisms in most developing country settings (Pandeya, 2015). Secondly, the level of citizen competence varies considerably between developed and developing countries, with the latter ones grappling with generally lower levels of competence, and thus, perceivably lower levels of political accountability. Thirdly, the low intensities of citizen competence among the vast majority of citizens in the developing world has undermined their influence in local governance, resulting in greatly uneven political accountability across these countries. The latter citizen attributes form part of the instruments for holding leaders politically accountable at district level, stopping leaders from using public offices for their own economic self-interests (Shah \& Shah, 2008). Considerably low citizen competence on the continent is mostly displayed by the economically disadvantaged citizens, especially women living in rural areas, with evidence suggesting widespread inactive citizenry who engage in local level meetings (Agyeman-Duah, 2010). Such relatively disengaged citizenship in Africa is associated with high levels of ignorance which imply inadequate capabilities among citizens for demanding political accountability. Such inadequacies in political knowledge, civic responsibilities and shortage of civic skills among citizens imply low elements essential to effectively participate in politics at the local level. Uganda's political space as assessed in the prism of district politics displays remarkably analogous low configuration of citizen competence levels akin to the rest of Africa (Kugonza \& Mukobi, 2016). This characterization suggests that while citizens paid taxes as responsible citizens and obeyed the laws, they did not keenly lay down their own priorities in line with their local needs (Tidemand, 2013).

Right from independence in 1962, Uganda had a constitution which allowed citizens to control the political actions of their leaders, implying that citizens were in position to demand for political accountability from their leaders at all levels. However, with the introduction of the 1967 constitution which instituted a shift from elected to appointed district councils, citizens lost their power over district leaders' actions. Another citizen disempowerment shift occurred in 1971 when the Idi Amin-led overthrow of Obote I government in 1971 resulted in militarised local governance, with the appointment of military officers as governors in charge of military and civil affairs (Golooba-Mutebi, 2008). As a military ruler who governed by 
decree, Amin granted provincial governors and appointed district commissioners unlimited powers to implement government programmes. Consequently, there was virtually no relevance for citizen competence for influencing political accountability in district politics during the military regime even after the 1979 fall of Amin's government spearheaded by the Uganda National Liberation Front (UNLF). Neither did Yusuf Lule as the first President under the UNLF government nor Godfrey Binaisa, who succeeded him, advance the cause for political accountability as these governments, similarly failed to launch any significant district-focused political reforms.

There were no changes made on the form, structure and character of local governance when the Obote II regime started in December 1980. The 1967 constitution which had essentially centralized most of the power, was back in operation. Therefore, in the same way, the Obote II regime was limited by the local governance landscape in which it operated in regards to the political relationship which existed between the citizens and the local state structures. The local leaders were appointed rather than elected, and could not, in this local governance setting be held to account by the citizens. Gradual democratization of local governance in Uganda began with the National Resistance Movement (NRM) regime which took over Kampala in January 1986. Operating in a significantly more democratic local governance system, the NRM launched a series of reforms, some of which form part of this paper's analysis. In other words, the colonial and most post-independence governments made attempts to model and re-model local governance structures but, in most cases, did not adequately provide for citizens' competence improvement initiatives targeting district level politics. Moreover, these efforts, likewise, hardly catered for related citizen empowerment avenues, particularly those planned to promote mechanisms within which to promote political accountability at the grassroots.

This account of the relationship between citizen competence and political accountability is analyzed further, comparing the Obote II government, which operated under a multiparty dispensation, and the Museveni-led NRM regime. The latter administration did not only institute its own local governance reforms from 1986, but also, like the former, operated under multiparty politics from 2006. Citizens were expected to increasingly hold their leaders politically accountable. The extent to which they were able to do so forms part of the analysis of this paper.

Guided by the public choice theory, this paper explores citizen competence during the Obote II and the NRM regimes to assess the democratic credentials of the two political eons. In particular, comparison is made between the two regimes focusing on the major dimensions of citizen competence which consist of political knowledge, civic responsibility and civic skills required to ensure political accountability at the grassroots. In this paper, citizen competence refers to mechanisms through which citizens have access to, relative control over the local decision-making process, and effective use of unique capabilities to effectively determine the local politicians' behavior. These fundamental parameters provide the basis on which citizen competence is expressed, partly through common preferences articulated in active attendance of community meetings and active membership of civil society groups. This study endeavors to answer research questions examining the linkages between citizen competence and how 
they influenced political accountability across regimes in Uganda during the post-independence period.

\section{Theoretical Framework/Analytical Framework}

The paper argues that citizen competence influences district level political accountability in Uganda through economic competitions to the extent that it is struggle for economic resources that effectively drives the behavior of those controlling local power. This argument is based on public choice theory (PCT) as advanced by James Buchanan, a Nobel laureate in economics. The PCT analyses cover diverse aspects of theory, central of which is the critical connection between the actions taken by the state in local governance settings and citizen behavioral characteristics as economically self-interested actors (Felkins, 2013).

The theory presents the following assumptions. First, and underlying PCT, is the assumption that economic interpretations of politics influence citizens' engagement in politics since their behavior is majorly motivated by the desire to maximize economic self-interest (Mariotti, 2016). Economic self-interest is the dynamic force of politics at different levels of governance, with citizens, for example, voting for the politician that they believe is likely to provide them with maximum opportunities to acquire welfare benefits. Second, each category of actors capitalizes on its economic interests at the expense of other categories, suggesting that each group pursues its interests while at the same time checking the excesses of other interested groups (Gustafson \& Hertting, 2016). Third, PCT assumes that what happens in the private marketplace also happens in the public one, with both marketplaces having some concern for others. Fourth, the common preferences by the citizens tend to differ from locality to locality in terms of priority within a country, justifying citizen participation in local governance since preferences and needs differ in diverse local units. These scholars further discuss the voters' economic self-interest, the politicians' and bureaucrats' economic interests as well as their rent-seeking behavior in the public market.

Public Choice Theory underpins the linkages between control of public resources by economically self-interested actors and political accountability in both the Obote II and the NRM regimes. This is true especially when a spotlight is laid on how public economic resources were utilized to influence political accountability at the local level. The theory facilitates the analysis of district politics and grassroots political accountability in Uganda by helping to explain the role of economic self-interest in both regimes' political settings. The underlying PCT assumption which is directly applicable to the bond between political control of public goods and influence of political accountability in Uganda's district politics relates directly to the first assumption of the theory. This fundamental postulation closely analyses the intricate relations between public goods control by actors whose motivation for engagement in politics is inspired by the desire to maximize economic self-interest, often resulting in the manipulation of political accountability at the grassroots.

Operating in line with the first PTC assumption were both the Obote II and the NRM regimes which effectively used public economic resources to sway political answerability. In the case of the former regime, voters at the district level were partly influenced to engage in the democratic process utilizing the publicly-supplied public goods such as sugar, soap, cooking 
oil and paraffin which were in short supply in 1980 following the 1979 Uganda liberation war (Rwehururu, 2002). Equally significant, appointed district bureaucrats and community leaders' public provisioning engagements were influenced by the promise of not only controlling the public supply system for scarce public goods but also opportunities for bureaucratic rent-seeking behaviour at district and lower levels. Besides, it was established that district politicians' actions were largely driven by economic self-interest. The district officials' actions during the Obote II regime involving voter intimidation, violence and massive population displacements in North West Uganda help validate the PCT. Beginning in 1979 after the fall of Amin, the public officials' activities were largely in pursuit of personal economic power, ultimately resulting in compromised political accountability ay the grassroots (Kabwegyere, 2000).

Conversely, during the NRM regime which began early 1986, a relatively similar set of political factors were identified and positively linked to the PCT fundamental postulation. Evidence which closely echoes the central PCT assumption can also be identified during this regime. Indeed, under the NRM, voters have been bribed by public officials with welfare items such as clothes, beddings, food items, cooking utensils, beverages, soap and sanitary ware as a way of influencing political accountability (Francis, 2003; Nakisanze, 2015). In addition, it was during the NRM regime when extensive use of money during electoral activities, largely associated with public officials, was first reported as an incentive to influence political accountability at the district level (Ceon-U, 2016). Held in phases for different levels, the electoral activities were marred by voter bribery at national and local levels, unquestionably underscoring another principle of PCT that looks at voters as chiefly motivated by economic self-interest which influences their political behaviour. Accordingly, the implication is that control of public resources by public officials influences political accountability as electoral malpractice incidents suggest in Uganda's district politics (Buntaine et al, 2018).

Similarly, PCT aids the scrutiny of local politicians' actions; essentially those which have been engaged in to influence political accountability throughout the NRM regime. Employing a diversity of public economic resources as incentives to voters and orchestrating electorate coercion under the NRM regime, the district officials sought to influence political accountability (Demgroup, 2016). Without a doubt, these interventions and politicians behaviour, mostly exhibited through use of public resources, mirror the PCT assumption about politicians' economic self-interests and have had inauspicious implications to political accountability at the district level (Deserrano, 2017).

\section{Methodology}

Based on documentary review, this study was conducted using an in-depth explorative design, heavily relying on the desk review analysis method, using the thematic analysis technique (Braun \& Clarke, 2013). Thematic analysis focused on examining themes within data to establish relationships of interest. The larger categories explored consisted of the contribution which citizen competence had made to the strengthening of political accountability, the ways in which citizens', politicians' and bureaucrats' economic interests had impacted on political 
accountability and the extent of civic engagement with civil society during the political regimes studied. The methodology involved gathering available scholarly and government publications in the area of local governance and analyzing the significance of citizen competence to the democratization process.

The results from the data sources were investigated as occasioned by public officials' control and use of public resources, the effects on citizens' levels of engagement in the political process at the grassroots. This process was used to explore the scale of citizen competence, nature, the extent of its expression in district level politics and how it was influenced by public officials' economic self-interest. This was done in order to assess the impact of citizen attributes on democratic shifts during the Obote II and the NRM regimes as well as the effect of public officials' behavior on political accountability at the grassroots. It was, in addition, adopted to assess the democratic credentials of the two political epochs within the overall liberal perspective the two regimes generally attempted to pursue. Specifically, comparison was made between the two regimes, basing on some of the central dimensions of citizen competence, namely political knowledge and civic responsibility, linking them to political answerability in district politics. Qualitative methods of data collection and analysis were adopted. These methods were suited for this study because of its interpretative nature, which emphasized developing a description of the settings in which the specific political regimes operated, and how they shaped Uganda's democratic process.

In terms of sampling methods, the general scholarly guidance adopted was to continue to collect data by reviewing secondary sources which consisted of academic journals, text books, relevant government and international documents. The data collection process continued until no further relevant sources emerged (Hammersley, 2015). The assumption was that saturation point would be reached when the most relevant documents no longer appeared in the searches. This is the point at which the researchers perceived they had reviewed adequate sources for reliable data on the link between citizen competence as influenced by economically self-interested public officials and political accountability in district politics. The inclusion criteria for the documents took account of the relevance of the item to the title, theses, peer reviewed items, age of item (i.e 1980-2018), and qualitative design sources.

At data collection stage, evidence about the general analyses on citizen competence and how it was economically manipulated to influence political accountability, provided the bulk of the sources from where we selected the relevant materials for further analysis. Most central among these included the internet, peer reviewed journals, books, working papers, theses, conference proceedings, government publications, district and civil society documents. Generally focusing on Uganda, the applicable documentary materials were selected according to time period and geographical space, resulting in several materials, running across political regimes, ranging from 1980-2018. This time frame was significant for analysis of the Obote II and NRM regimes in the perspective of citizen competence and political accountability.

Data analysis was conducted following the recommended steps for thematic analysis which require investigators to identify initial themes and concepts, label or tag the data, sort the data by category and theme, edit and summarize or synthesize the data to come up with coherent 
and valid study conclusions (Braun and Clarke, 2006).Thus, to effectively identify all the features and relevant themes related to citizen competence, control of public goods and political accountability in local governance in the data collected, systematic phases of the thematic analysis technique were embarked upon. These consist of familiarizing oneself with the data, generating initial codes, identifying themes from the data collected, constructing thematic network, integrating and interpreting the data to make logical conclusions (Robson 2011).

The transcription process for all the data collected for the study produced a 42-page data set for further processing. Again, to ensure the highest quality of the study results possible, we took utmost care to focus on noting down the key variables in the data set to make certain that all details relevant to the citizen competence and political accountability relationships in district politics were captured. This was followed by the effort to recognize and identify the concepts, messages, patterns, associations and meanings of the data. We assigned the initial codes to the findings. The codes consisted of "CC1", "CC2" ... and "PA1", "PA2", "PA3" .... respectively for citizen competence and political accountability data elements. This was accomplished essentially by analyzing the grouped texts that had similar meanings. In this process we were able to define what the data were all about, effectively executing this through combing the entire data set to discover logical associations with the variables of interest.

The codes were electronically extracted from the main document and organized into a final electronic document. Consequently, the most important themes identified consisted of "citizen competence", "political knowledge", "informed citizenry", "citizen intelligence", "citizen engagement", "sense of civic responsibility", "citizen concern", "citizen participation and council actions", "local citizens' groups", "voluntary groups in local governance", "public goods control and usage", "civil society", "economic interests", and "citizens' local preferences". On the other hand, we also identified "political answerability", "governance indicators", "local state capture", "political accountability" and "district politics" as the main themes in line with the political accountability variable. Focusing on citizen capabilities and government practices, we also identified "district politics during Obote II regime" and "district politics under the NRM" as equally appropriate themes to guide analysis.

This study endeavored to answer questions examining the relations between citizen competence as conditioned through control of public goods by state officials and how political accountability was influenced during the Obote II and NRM regimes in Uganda. We explored how citizen competence had influenced political accountability mechanisms in district level politics, the ways in which citizens', politicians' and bureaucrats' interests had affected political accountability and the extent of civic engagement with civil society during the regimes studied.

\section{Results and Discussion}

\subsection{Introduction}

These results are presented and discussed based on specific research questions/themes, viz 
citizen competence contributions to political accountability; factors in citizens', politicians', and bureaucrats' interests across regimes; citizen engagement in civil society and political accountability in district level politics. These research themes are examined in the following sections.

\subsection{Citizen Competence Contributions to Political Accountability in District level Politics}

From the data analysis, a trend which indicated contrasting levels of citizen competence between the Obote II and the NRM regimes emerged. The findings on political knowledge were assessed based on essential attributes consisting of possession of factual information held by a citizen about public matters, citizens' awareness of their political rights, freedoms, choices, and knowledge of legislated roles. The findings in this theme are organized in five distinct results categories observed from data analysis. Firstly, comparing the two regimes, it emerged that in terms of trends, there was more political knowledge during the NRM than the Obote II regime, with a drift indicating slightly improved political awareness which matched with growing citizen engagement with the state during the NRM period (Oloka-Onyango, 1989; Kakumba 2010). This trend was largely shaped by the differences in the local governance structures between the two regimes. For example, whereas the local governance arrangements enabled the centre to control most local matters, including scarce public goods during the Obote II regime, the NRM started the power devolution process to the districts early in its administration, constitutionalizing decentralized powers in 1995 (Uganda, 1995).

Secondly, results highlighted the nature of citizen competence in both regimes, with substantial findings suggesting that economic self-interest motivated local actors to engage in district politics, a point emphasized by the PCT (Boyne, 1997). Accordingly, results indicate the association between economic self-interest and grassroots political accountability by depicting the role of public goods usage in the political settings of both regimes under comparison, but with more pronounced economic self-interest displayed under the NRM. In this perspective, results indicate forces determining citizens' behaviour in respect of state engagement in district politics. For the case of the Obote II regime, citizens at the district level were partly moved to engage in the democratic process incentivised by the centrally-supplied welfare provisions, in short supply during this period. Comparatively, there were widespread experiences of voter bribery at the local level as an incentive to influence political accountability regardless of the local common preferences during the NRM regime (Demgroup, 2016; Nakisanze, 2015; Black Monday, 2015). Thirdly, findings established that appointed district officials and community leaders' political engagement levels were framed by the prospects for eventual control of the public goods supply system at the grassroots (Mwakikagile, 2012).

Nonetheless, economic self-interest by diverse local actors aside, citizens were able, in varying degrees to enforce political accountability during the multiparty political era under both the Obote II and the NRM regimes. While current information confirms the attempts by both the Obote II and NRM regimes to bolster citizen competence through diverse policy actions, both regimes appear to have been off the mark as far as citizen competence contributed to the enforcement of political accountability (Sematimba, 2013). In the case of 
the Obote II regime, the source of the challenge for citizen competence shortfalls stems from the state's efforts to centralize all local governance powers, thus leaving the district councils as instruments for executing central government preferences rather than those of the local citizens (Ocaya-Lakidi, 1982). Consequently, citizens were alienated by the nature of politics as assessed at the district level. This is partly the reason why there is modest evidence of the connection between citizen competence and its contribution to enforcement of political accountability. Citizens during this regime were largely left out of the loop in local decision-making mechanisms at the district level. They were, thus, unable to contribute to political accountability enforcement.

On the part of the NRM regime, there is evidence supporting the view that the state spearheaded deliberate policy reforms, mainly summarized in the LGA 1997 to boost citizen competence for the overall good of the local governance system. Indeed, the NRM introduced major local governance changes aimed at creating avenues for citizen influence in setting priorities and preferences. Nonetheless, as evidence suggests, these reforms were yet to translate into effective sustainable political accountability mechanisms and shared development benefits for all at the grassroots. Part of the explanation for this non-occurrence was the control of public goods, largely deployed to disenfranchise ordinary citizens where majority live in poverty. Current evidence also shows that the contradictions threatening the relationship between citizens' inability to influence the local governance system emerge from the declining village meeting attendances and voter bribery (Demgroup, 2016). These are some of the elements adduced in the charge that the local governance system in Uganda is progressively being captured by the local elite aided by patronage systems from the centre. This evidence is partly supported by the district creation wave in recent years, jointly driven by the centre and the local elite (Green, 2010).

Fourthly, the study established that while citizen competence was a supportive factor for political accountability in a democratic society, citizens in Uganda were largely inarticulate, disengaged and uninvolved in determining local preferences (Kakumba, 2010). This political reality suggests minimal link between citizen competence and citizens' propensity for contributing to political accountability in district politics. More pertinent data indicated that citizen competence was less influential in contributing to the achievement of political accountability for the greater part of the post-colonial period. This analysis is true for both the Obote II period (Sathyamurthy, 1982) and the NRM regime despite evidence of better citizen engagement opportunities during the latter regime. It would, therefore, be logical to argue that whereas there were more opportunities for citizens to enforce political accountability under the NRM than the Obote II regime; citizens under the former regime appear not to have been able to better contribute to political accountability. The rational explanation for this political experience is partly imbedded in the structural design for local governance under the NRM which gave immense political, legislative, administrative and development powers to district political and bureaucratic leaders. Furthermore, the patronage relationship between the district politicians and the centre which is not based on advancing democratic aspirations but rather economic self-interest vindicates the relevance of the PCT in analyzing local governance issues. 
Fifthly, equally significant were results which indicated a strong association between citizen characteristics such as low political participation and low community organization involvement on one hand and reduced enforcement of political accountability in district politics, on the other. This comprises, for example, reduced attendance of community meetings and the prevailing political culture, characterized with disinterest in community matters in both regimes. In other words, regardless of the level of political awareness and irrespective of the regime under discussion, the intensity of citizen competence was too low to contribute to political accountability. However, results suggested much less civic competence during the former political establishment partly due to few opportunities for citizen to influence district politics. These data overall suggest that in both regimes citizens were less positioned to contribute to political accountability, but much less so during the Obote II regime.

\subsection{Factors in Citizens', Politicians'and Bureaucrats'Interests Across Political Regimes}

This section seeks to explore the ways in which diverse factors shaped citizen competence, district-based politicians' and bureaucrats' interests on one hand and how these relationships impacted on political accountability. The study results highlight contrasting trends in the political interfaces involving citizens', politicians' and bureaucrats' interests but with slightly different variations in the nature of effects on political accountability in the district level politics (Humphreys \& Weinstein, 2012). One of the fundamental findings was the deeply collusive interfaces between politicians and the bureaucrats which existed in both the Obote II and NRM regimes, albeit with much less intensity in the former than the latter regime. Utilizing the PCT framework, we found out that an unprincipled relationship between district-based politicians and bureaucrats, wholly inspired by public resource exchanges or their promise, existed during the Obote II regime (Golooba-Mutebi, 2008). On the other hand, while the economically self-interested behavior between these sets of public officials was low key early in the NRM establishment, over time a complex system of patronage, stretching from the central government, has emerged. A further inclination in this patrimonial system, which undermines political accountability mechanisms, appears to be increasingly materializing during the NRM period.

In a endorsement of the PCT logic, the study results further indicated the nature of political sponsorship in district politics which has emerged in recent years under the NRM tenure. Current evidence underscores financial incentives observed in district creation dynamics as the most central factors in the patronage system that sidesteps ordinary citizens (Green, 2010; Brock, 2004). Consistent with these findings, is a World Bank (2008) study on local council oversight and social accountability in Uganda which concurs with this study outcomes. The overall data suggest relatively similar factors which constrained citizens' contribution to political accountability enforcement in district politics under the NRM. Fundamental among these sets of factors is the association between citizen competence and political accountability which is partly determined by the flexibility of district structural establishments, existing policies, participation mechanisms, the amount of bureaucratic power existing in the administrative system at the local level and the operational environment. Moreover, other relevant findings suggested the presence of rigid and powerful district bureaucracies in 
Uganda which suffocated political accountability (Humphreys \& Weinstein, 2012).

Results indicate that district politics during the Obote II regime were influenced by socio-economic factors; specifically, the commodity shortages which essentially influenced behaviour and politicians' practices as they were incentivised, in some cases, to orchestrate violence and intimidation against ordinary citizens. Relatively comparable dynamics were identified in the findings relating for the NRM period. For example, regardless of the periodic elections for the district political leadership up to the lower levels during this period, underlying forces, including poverty, effectively determined voters' choices during both national and district level elections (Mwakikagile, 2012).These results are underscored by recent similar evidence which indicates that voters were bribed with welfare items and basic essentials consisting of food items, beverages, cleaning materials and cooking utensils as stimulus for district based voters (Nakisanze, 2015). This evidence is supported by other election related data which show that during the NRM regime there has been widespread use of financial resources as an enticement for citizens to vote local leaders, effectively undermining political accountability (Ceon-U, 2016).

In regard to public services enjoyed by all citizens consisting of roads, hospitals, water, schools, electricity, agricultural initiatives, the study found out that citizens maximised the common interests across the Obote II and the NRM administrations. Results indicate, however, that in two of the economic self-interest areas, citizens were better able to enjoy these services under the Obote II than the NRM political dispensation (Mujaju, 1999). This analysis is based on the comparative numbers of secondary schools established during the relatively short duration of the former regime compared to the latter. Current data indicates relatively slower growth of public secondary education under the NRM, in power for over 30 years since 1986, than was the case under the Obote II (Mwakikagile, 2012). The data on different accomplishments across regimes have been perceived in terms of regime priorities and the exigencies of the liberalization era under the NRM.

There are clearly other economic interest areas such as local roads which are under districts, where the NRM has by far done better; indicating that irrespective of citizen competence level shortages, the longevity of a regime was a significant factor in explaining political accountability (Golooba-Mutebi, 2016; Muyomba-Tamale, et al. 2011). In other words, regardless of the multiparty political environment in both regimes, the citizens under the Obote II regime had by far much fewer prospects for expressing their economic self-interest and even much less avenues for influencing political accountability. Nonetheless, these citizens appear to have collectively benefited more from the state than their counterparts under the NRM as far as education and agriculture are concerned. Citizens under the Obote II regime were governed under the 1967 constitution which had centralized most political power (Sathyamurthy, 1982). In contrast, the citizens under the NRM regime who benefited from relatively more democratic district politics since 1986 appear to have engaged the local state differently. This is despite the extensive decentralized powers; responsibilities and services particular to the district as per the 1997 LGA which seem not have adequately empowered the citizens to demand for improved political accountability (Uganda, 1997). 


\section{Mll Macrothink}

Journal of Public Administration and Governance

ISSN 2161-7104

2020, Vol. 10, No. 3

These findings in their entirety are noteworthy in the analysis concerning the links between citizen competence and political accountability across regimes in post-independence Uganda. One, with reference to the ways in which diverse factors impacted on citizen competence, analysis focused on two district-based actors, namely, the politicians and bureaucrats. The interests for these two groups depressingly affected political accountability in both regimes as their economic self-interests overshadowed democratic ideals at the local level. Two, some significance has been put on duration of a political regime as a factor. However, longevity as a factor, regardless of the intensity of citizen competence, determined the extent to which political accountability in the two regimes was observed. While the Obote II regime was short-lived, lasting for only 5 years, the NRM one has now been in power for 33 years. In addition, whereas constitutional and administrative limitations could be cited as institutional issues that limited citizen competence during the Obote II regime, regime durability is another dynamic which likely undermined political accountability unlike the NRM's which is still ongoing. On the other hand, a more liberal constitution and decentralized governance during the NRM comparatively longer regime allows more elaborate insight into the political and bureaucratic interests which undermine political accountability at the district level.

Three, the study has brought to light the slightly contrasting strengths, patterns and trends in citizen competence and the political accountability involving citizens', politicians' and bureaucrats' interests during the two regimes explored in this paper. It has also underlined the slightly divergent nature of effects arising from economic self-interests on political accountability in the context of district level politics. Moreover, the results stress the reasons for the similarities and contrasts in citizen competence and how the district-based actors' economic self-interests have negatively affected political accountability. A key discussion point, nonetheless, is the corrosive nature of these economic self-interests, specifically in the way they undermine citizen competence and automatically political accountability. Thus, citizen competence and nature of local governance in Uganda mirror the political accountability practices at this level. Results show slightly improved civic competence levels during the NRM regime than during the Obote II regime, but with surprisingly relatively similar patterns of political accountability at district level during both regimes.

The implication is that political accountability in district politics is heavily compromised by voter inducements, determining the nature of political accountability at the grassroots (Buntaine et al, 2018). These findings further confirm the significance of the PCT framework, centre of which is the economic self-interest as an incentive, in exploring citizen competence and political accountability in district politics during the periods studied. Holding politicians accountable via elections is a fundamental precursor to effective governance, economic development, and high-quality public service delivery at the local level. However, political accountability will not be realized at district level if citizen competence is inadequate.

\subsection{Citizen Engagement in Civil Society and Political Accountability at District Level}

A discussion on how citizens have engaged civil society across regimes during post-independence Uganda constitutes the final section of this study. The findings in this study indicated several political realities about the significance of citizen competence and 
political accountability in district politics. Firstly, we established that the intensity of civil society engagement by citizens was a key indicator for civic responsibility among citizens in the regimes studied. With both regimes beginning at a time the state was rebuilding itself after protracted political conflicts involving civil wars, the role of civil society in both the Obote II and the NRM regimes was equally significant in local governance. However, evidence of levels of citizen engagement with civil society at district level became more apparent during the NRM regime as the LGA 1997 provided for civil society operations to be overseen by the district council (Makara, 2003). Secondly, the results suggest that due to the local governance legal framework which put civil society organizations under the supervision of district councils during the NRM era, and the consequent interface between citizens and these organizations, civic responsibility appeared more evident under the NRM than during the Obote II regime (Barr, Fafchamps, Owens, 2003).

In other words, the good governance requirements on civil society by the state, which called for more disclosures and visibility at the community level, contributed to the perception that there was higher intensity of citizen competence than under the Obote II regime. This logic would suggest that there was more political accountability under the NRM than the Obote II regime. Thirdly, it was established that civil society actors, whose focus was closely associated with citizens, was equally influenced by economic self-interest, achieved through the pursuit of rational decisions in local political settings. This analysis is inspired the fundamental PCT postulations which are centred on the premise that most individual actors are driven by economic self-interest. Accordingly, the research found out that PCT basically assisted to ease analysis of the degree of citizen competence and self-interested behaviour in the regimes studied during Uganda's post-independence period. This exploration was done in order to understand the connection between citizen competence and political accountability.

The variables assessed in the study consisted of citizens' behaviour as understood in respect of the levels in membership of civil society organizations, voluntary contributions, abilities to make public decisions, mobilization to build teams and citizen understanding of local level interests (Font, Wojcieszak \& Navarro, 2015). Founded on the parameters identified, a comparison of civic responsibility between the Obote II and NRM regimes found out that in both political settings citizens were evidently uninvolved, unmotivated, but with slightly more engagement of citizens with civil society under the NRM regime. The analysis derived from the PCT framework in relation to these findings is that citizens' behaviour is linked to the dire economic conditions of the individual grassroots people who do not have ability to engage in civil society activities, regardless of the intensity of civic responsibility levels for citizens in both regimes studied. Moreover, from a PCT perspective, related findings show that citizens' economic self-interests are similarly underscored in financial mobilization drives, advocacy, sponsorship and citizens' community groups, which are, but part of the evidence for civic responsibility (Bossuyt, 2000). Nonetheless, the interpretation of these findings in light of PCT implications means that civic responsibility in post-independence Uganda remains relatively weak in both regimes. Consequently, in both regimes studied, the contribution by civil society has been inadequate to improve citizen competence and political accountability in Uganda's district politics. These analyses similarly suggest that citizen 
competence during the Obote II and NRM regimes was insufficient to effectively contribute to political accountability.

Equally pertinent results suggest that to understand civic responsibility during post-independence Uganda, specifically focusing on the Obote II and NRM regimes, the PCT perspective has to be adopted in the analysis. Indeed, put in the PCT paradigm, it becomes understandable why available data indicates less involvement in civil society activities by citizens during the Obote II regime (Barr, et al. 2003). Scholars have argued, in some data which this study partly uses, that individual citizens in most cases have clear motivations that drive their civil society engagement orientations (Tijunaitiene \& Bersenaite, 2011). One way to understand these results is to present the contrasting epochs which have been explored in this study. In the first place, there was no state legal framework within which civil society organizations were operating at the district level during the Obote II regime beyond simple registration with the Ministry of Internal Affairs, unlike the situation under the NRM.

This implies a gap for institutionally tracking the citizen engagement scope with civil society under the former regime, and thus, a relative difficulty in assessing the linkage between civic responsibility and political accountability during this period. Secondly, conceptually, the PCT argument would relatively be limited in assisting the comparison between the two regimes explored because of inadequate data for the Obote II regime on citizen engagements with civil society. The other realistic view in regard to the apparently low civic responsibility levels in both regimes is related to the veracity of civil societies' activities which involve a lot of voluntarism and philanthropy. Therefore, just like during the NRM regime, PCT provides a realistic justification on why civic responsibility was low in both regimes since civil societies do not support the economic self-interest thesis which PCT raises. The latter organizations mostly target the "poor of the poor" as their clients. Nonetheless, with the available information, it can generally be argued that there was relatively less civic responsibility during the Obote II regime than during the NRM period.

Further, citizen mobilization and team-building in a way fall within the perspective of PCT since they also call for the individual financial abilities of the citizen (De Coninck, 2004). This reality also likely explains why most civil society interventions focus on the "poor of the poor" concept in order to identify the individual citizens whose economic conditions are worse off. Therefore, the analysis focusing on the relationship between citizen competence and political accountability logically suggests that civic responsibility was low in both regimes explored, although there was evidence for slightly more engagement with civil society by citizens during the NRM period. This finding further points to the limited nature of citizen competence resources for enforcing political accountability in district politics during both the Obote II and NRM regimes.

Results analysed by this study indicate that the performance of citizens as it related to civil society actors at the local level was relevant in the investigation of citizen competence and political accountability. Exploration of citizen competence during the Obote II and the NRM regimes using the PCT postulations reveals other similarities and contrasts of the two political regimes. Firstly, comparison was made between the two regimes focusing on one of 
the major dimensions of citizen competence namely, the sense of civic responsibility at district level. This study specifically assessed data on active attendance of community meetings and membership of local civil society groups to assist in putting citizen competence in the perspective in the two regimes. It was found out that almost the same way, the attendance of community meetings was equally low for citizens in both regimes.

While some findings indicated the citizen engagement with civil society had increased the mechanisms for participation opportunities particularly during the NRM period, they did not make a real difference in decision-making at the district level and lower councils (Makara, 2003). This view is further explained as a result of low scale of civil society operations which were often just used to meet legal and institutional requirements, especially under the LGA 1997 during the NRM regime. This result essentially means a profound limitation. Sometimes, some mechanisms were misused to the advantage of the local political elites. Results also indicated that although there were more opportunities for participation than in the Obote II regime, the limitations in civil society also constituted a constraint for citizens to influence the local decision-making process during the NRM regime (Tidemand, 2013). In addition, some data sources suggested there was a shortage of financial wherewithal as a major restriction on citizen engagement opportunities with civil society. These results demonstrate that citizens under both regimes lacked opportunities for effective demand for political accountability due to the inherent weaknesses in citizen competence, itself dependent on a number of factors such as resource availability in both regimes. In the final analysis the results, overall, suggest that the citizen engagement with civil society mechanisms have greatly widened the scope of citizens to hold their leaders politically accountable. In reality, however, due to diverse factors both from the centre and district politics under both the Obote II and the NRM regimes, citizen engagement was inadequate to empower citizens who should have in turn been in position to enforce political accountability.

\section{Conclusion}

This work has analyzed the link between citizen competence and district politics within the context of Uganda's local governance. It has particularly focused on the role of citizen competence in enforcing political accountability at the grassroots during the post-independence period. The paper demonstrates that irrespective of the political context, citizen competence, which is expressed in form of political knowledge, a sense of civic responsibility and civic skills, is central since it is a central determinant in local political influence by citizens to determine their local priorities and enforcement of political accountability. The analysis in this research is based on three central issues which we attempted to address. These sought to highlight how citizen competence had influenced political accountability mechanisms in district level politics, the ways in which citizens', politicians' and bureaucrats' interests had affected political accountability. In addition, the study explored the extent of citizens' engagement with civil society during the political regimes studied. The research also examined how citizen engagement with civil society has been displayed across regimes in post-independence Uganda.

Results presented in this paper are in a way authenticating the essential economic realities 
such as the dynamics, centre of which is control of public goods and economic self-interest, which tend to strengthen or dampen the drive for political. The question answered in this analysis, which is particularly relevant for policy-makers in the developing world, was on the role of economic incentives in shaping governance relationships at the local level. We demonstrate that PCT ably guides analysis of the ramifications involving citizen competence and political accountability at the local level. However, there is a basic scholarly gap that remains, which is how to structure the PCT implications into government interventions at the local level. This is necessary to respond to the political and bureaucratic economic interests, which together, undermine the effort for enforcing political accountability at district level regardless of the levels and patterns of citizen competence from regime to regime. The policy response would also address the issues raised in relation to civic responsibility as a dimension of citizen competence. The analytical gap that we partly fill is the challenge that local level bureaucracies have to perform manifold composite tasks, involving diverse intricate functions in infrastructure, agriculture, health and education services delivery; without addressing issues of economic self-interest which PCT raises at a theoretical level. Recent evidence on how to structure the economic self-interest which the PCT emphasizes is inadequate. A comprehensive policy response in this area would constitute deliberate state intervention for mobilization of citizens and the establishment of state-engineered dynamic social networks to generate capacity for holding local leaders politically accountable.

Thus, this paper contributes to understanding local democracy and the central role of citizen competence as it shapes the level, scope and pattern of political accountability. The research also identifies the opportunities and limitations of citizen competence as well as the dynamics that determine citizen competence across regimes especially from the perspective of public goods' control in a poor country. Indeed, recent data raises an open question on the larger issue of the extent of the relationship between citizen competence and political accountability enforcement in light of more than three decades of reforms towards establishing improved local level governance in developing countries (Shah \& Shah, 2008). In this paper, we have shifted the research agenda away from merely comparing local service provision mechanisms (Gaventa, 2004) and steered it towards exploration of the essential role of the individual citizen in enforcing political accountability across political regimes. We have, therefore, through the PCT framework of analysis sought to position the debate on multifaceted local governance issues which impinge on the processes for citizen competence and political accountability.

\section{Acknowledgement}

We wish to appreciate the contribution of colleagues who read and provided critical peer review feedback to this paper.

\section{References}

Agyeman-Duah, B. (2010). Elections in emerging democracies: Ghana, Liberia and Nigeria. Critical Perspectives No. 4. Available from: http://www.cddghana.org/publications/Critical-Perspectives/Critical-Perspectives-No-4-\%5B Elections-in-Emerging-Democracies-Ghana-Liberia-and-Nigeria-\%5D 


\section{$\triangle 1$ Macrothink}

Journal of Public Administration and Governance ISSN 2161-7104

Barr, A., Fafchamps, M., \& Owens, T. (2003). Non-governmental organisations in Uganda. A report to the government of Uganda. Oxford: Oxford University Press.

Black Monday. (2015). Electoral corruption at local government: a double loss for citizens, Issue 25, March 2015.

Bossuyt, J. (2000). Involving non state actors and local governments in ACP-EU dialogue. Policy Management Brief, No. 13.

Boyne, G. A. (1997). Public choice theory and local government structure: an evaluation of reorganisation in Scotland and Wales. Local Government Studies, 23(3), 56-72. https://doi.org/10.1080/03003939708433876

Braun, V., \& Clarke, V. (2006). Using thematic analysis in psychology. Qualitative research in psychology, 3(2), 77-101. https://doi.org/10.1191/1478088706qp063oa

Braun, V., \& Clarke, V. (2013). Successful qualitative research: A practical guide for beginners. London: Sage.

Brock, K. (2004). Context, Rules, Participation and Exclusion: Spatial Dynamics at the District Level and Below. In: Brock, K.; McGee, R., Gaventa, J. (eds). Knowledge, Actors and Spaces in Poverty Reduction in Uganda and Nigeria, Kampala: Fountain Publishers.

Buntaine, M. T., Jablonski, R., Nielson, D. L., \& Pickering, P. M. (2018). SMS texts on corruption help Ugandan voters hold elected Councilors accountable at the polls, PNAS June 26, 2018115 (26) 6668-6673. https://doi.org/10.1073/pnas.1722306115

Citizens Election Observers Network-Uganda (Ceon-U). (2016). Uganda: General Elections 2016- Revisiting the Democracy Construct, Kampala: CEON-U. Available on https://www.ccedu.org.ug/index.php/publications/publications/reports/23-ceon-report/

De Coninck, J. (2004). The State, Civil Society and Development Policy in Uganda: Where are We Coming from? In: Brock K, McGee R, Gaventa, J. (Eds.), Knowledge, Actors and Spaces in Poverty Reduction in Uganda and Nigeria. Kampala: Fountain Publishers.

Demgroup. (2016). Uganda Presidential, Parliamentary, and Local Council Elections, 18 February 2016, Final Report. Kampala: European Union Observation Mission.

Deserrano, E. (2017). Financial Incentives as Signals: Experimental Evidence from the Recruitment of Village Promoters in Uganda. Global Poverty Research Lab Working Paper, No.17-105. https://doi.org/10.2139/ssrn.3126459

Felkins, L. (2013). Introduction to public choice theory. Available from: http://perspicuity.net/sd/pub-choice.html (Accessed 6 July 2017).

Font, J., Wojcieszak, M., \& Navarro, C. J. (2015). Participation, representation and expertise: Citizen preferences for political decision-making processes. Political Studies, 63(1), 153-172. https://doi.org/10.1111/1467-9248.12191 
Francis, P. J. R. (2003). Balancing rural poverty reduction and citizen participation: the contradictions of Uganda's decentralization programme, World Development, 31, 325-337. https://doi.org/10.1016/S0305-750X(02)00190-0

Golooba-Mutebi, F. (2008). Politics and local government in Uganda. In F. Saito (ed), Foundations for local governance: Decentralization in comparative perspective (pp.137-164). London: Springer. https://doi.org/10.1007/978-3-7908-2006-5

Golooba-Mutebi, F. (2016). Cost of politics in Uganda. Background Paper. Available from: www.wfd.org/wp-content/uploads/2016/07/Uganda-Cost-of-Politics.pdf (Accessed 9 July 2017).

Green, E. (2010). Patronage, district creation, and reform in Uganda. Studies in comparative international development, 45(1), 83-103. https://doi.org/10.1007/s12116-009-9058-8

Gustafson, P., \& Hertting, N. (2016). Understanding participatory governance: An analysis of participants' motives for participation. The American Review of Public Administration, 47(5), 538. https://doi.org/10.1177/0275074015626298

Hammersley, M. (2015). Sampling and thematic analysis: A response to Fugard and Potts. International Journal of Social Research Methodology, published online.

Humphreys, M., \& Weinstein, J. M. (2012). Policing politicians: Citizen empowerment and political accountability in Uganda-Preliminary Analysis (International Growth Centre, London).

Available

at

www.theigc.org/wp-content/uploads/2015/02/Humphreys-Weinstein-2012-Working-Paper.pd f. (Accessed February 19, 2018)

Hyden, G., Court, J., \& Mease, K. (2003). Government and governance in 16 developing countries. World Governance Survey Discussion Paper 6. Overseas Development Institute. https://www.odi.org/sites/odi.org.uk/files/odi-assets/publications-opinion-files/4102.pdf (Accessed August 11, 2017)

Kabwegyere, T. B. (2000). People's choice, people's power: challenges and prospects of democracy in Uganda, Kampala: Fountain Publishers. http://www.kas.de/wf/doc/kas_21611-1522-2-30.pdf?110113145556

Kakumba, U. (2010). Local government, citizen participation and rural development: Reflections on Uganda's decentralization system. International Review of Administrative Sciences, 76(1), 171-186. https://doi.org/10.1177/0020852309359049

Kugonza, S., \& Mukobi, R. (2016). Public participation in services delivery projects in Buikwe District Local Government, Uganda. Commonwealth Journal of Local Governance, 18, 127-146. https://doi.org/10.5130/cjlg.v0i18.4846

Makara, S. (2003). NGOs in Uganda: their typologies, roles and functions in governance. Kampala: Makerere University Institute of Social Research. 
Mariotti, S. (2016). What every voter should know about public choice theory. Available from:http://www.huffingtonpost.com/steve-mariotti/what-every-voter-should-k_b_8217650.h tml.

Mujaju, J. (1999). Uganda's age of reforms - a critical overview. Kampala: Fountain Publishers.

Muyomba-Tamale, L., Ssemakula, E. G., Luba, D., Ssempala, D., \& Jones, E. (2011). Local government councils' performance and public service delivery in Uganda: Mpigi district council score-card report 2009/10. ACODE Policy Research Series No. 48. [Online]. Retrieved on August 12, 2014 from http://www.acode-u.org/documents/PRS_48.pdf

Mwakikagile, G. (2012). Obote to Museveni: Political transformation in Uganda since independence. Dar es Salaam: New Africa Press.

Nakisanze, S. (2015). Plates, Pans, or Cash: Vote Buying Common as Ugandans Prepare for Election, $5^{\text {th }}$ Anti-Corruption Convection, Kampala: Africana Hotel. https://globalpressjournal.com/africa/uganda/plates-pans-cash-vote-buying-common-ugandan s-prepare-election/

Ocaya-Lakidi, D. (1982). From Local Governments to mere Local Administrations, 1949-1972. In: Uzoigwe, G.N. (Ed.), Uganda: The Dilemma of Nationhood. New York London Lagos: NOK Publishers International.

Oloka-Onyango, J. (1989). Law, "Grassroots Democracy" and the National Resistance Movement in Uganda. International Journal of Sociology of Law 17:465-480.

Pandeya, G. P. (2015). Does citizen participation in local government decision-making contribute to strengthening local planning and accountability systems? An empirical assessment of stakeholders' perceptions in Nepal. International Public Management Review, 16(1), 67-98.

Robinson, M. A., Sparrow, P. R., Clegg, C., \& Birdi, K. (2007). Forecasting future competency requirements: A three-phase methodology. Personnel Review, 36(1), 65-90. https://doi.org/10.1108/00483480710716722

Rwehururu, B. (2002). Cross to the Gun: Idi Amin and the Fall of the Uganda Army. Kampala: Monitor.

Sathyamurthy, T. V. (1982). Central-Local Relations: The Case of Uganda. Manchester Papers on Development, Issue No. 0260-8235, Department of Administrative Studies, Manchester University Press.

Sematimba, A. (2013). How the local council outlived its usefulness. Available from: http://campusjournal.ug/index.php/special-report/analysis/630-how-the-local-council-outlived -its-usefulness (Accessed 2 July 2017).

Shah, A., \& Shah, A. (2008). Demanding to be served: Holding governments to account for improved access. Washington D.C: World Bank. https://doi.org/10.1596/1813-9450-4643 


\section{Macrothink}

Journal of Public Administration and Governance ISSN 2161-7104 2020, Vol. 10, No. 3

Tidemand, P. (2013). The resistance councils in Uganda: A study of rural politics and popular democracy in Africa. Roskilde: Roskilde Universitet.

Tijunaitiene, R., \&Bersenaite, J. (2011). Citizens' intentions to participate in civil society

organisations. $\quad$ Engineering
https://doi.org/10.5755/j01.ee.22.2.313

Uganda. (1995). The 1995 Uganda Constitution, Government Printer: Kampala.

Uganda. (1997). The Local Governments Act 1997, Government Printer: Kampala.

World Bank. (2008). Africa local council oversight and social accountability (alcosa): Studying local council oversight in Uganda. Available at siteresources.worldbank.org/ ExtsocialdevelopmenT/Resources/2443621170428243464/3408356-1170428261889/340835 9-1242412320366/uganda_stageIId.pdf. (Accessed December 14, 2018).

\section{Copyright Disclaimer}

Copyright for this article is retained by the author(s), with first publication rights granted to the journal.

This is an open-access article distributed under the terms and conditions of the Creative Commons Attribution license (http://creativecommons.org/licenses/by/4.0/). 